\title{
Leader's Strategy in Building Organizational Commitment
}

\author{
Achmad Supriyanto \\ Educational Administration, \\ Faculty of Education, Universitas Negeri Malang \\ Malang-Indonesia \\ aspriess@gmail.com
}

\begin{abstract}
This article aims to explore a leader's strategy in building organizational commitment. The development of this topic is based on a critical review of the literature. The discussions are directed to find the base of leaders` strategy in building organizational commitment. Results show that the effective strategies in fostering employees' commitment are perceived as the efforts of leaders in motivating people, self discipline improvement, coordinating the units, involving employees in related activities, and provide multi way communications with all members of organization.
\end{abstract}

\section{Keywords - Leader`s strategy, organizational commitment}

\section{INTRODUCTION}

Every organization consists of collection of people who are active to optimize their resources by giving priority of quality aspects to achieve the objectives that have been formulated. Such thing cannot be achieved without good systems and should be pursued by a leader with the best strategy. Many factors influence the realization of the future organization. They are commitment, motivation, and discipline of the leader and organization members as the human resources. Furthermore, non-human resources factors also endure achievement in realizing the organization's goal in the future.

One of researches shows that the commitment, motivation, and discipline of leaders and subordinates become a critical success of qualified organization. [1] The quality organization requires three variables synergistically. Commitment refers to the attachment of a person on the achievement of organizational goals. Motivation refers to the Internal and external encouragement to move someone to achieve the organization's goal. Discipline refers to an individual consciousness, which is always obedient and submissive to the rules that have been defined in order to achieve objectives.

The problems of organization's commitment based on observation in recent show that there is lack of individual commitment when decisions of implementing the programs to achieve organizational goal are made. They tend to be committed to the programs, which have benefit rather than those that are not unfavorable in their direct financial aspects. They are more committed to the individualistic interest rather than to successful achievement of organizational goals. The result of organizational programs cannot be executed correctly, if it is not favorable for these individuals, who are concerned not to perform the tasks. Therefore, the results are unacceptable, and the purpose cannot be achieved.

Some researches related to organizational commitment, among others, are conducted by Buchanan [2] who has shown that managers working in government organizations have a lowe commitment than the executives who work in private companies. Managers who work for the government are generally less involved and less loyal than the business executives; and also conclude the same thing when comparing the relative commitment of employees between public organizations and private organizations. It means that organizational commitment of public and private employees are different. [3]

The employees who have high organizational commitments will be more motivated to get involved in organization and to achieve goals. [4] The organizational commitment relates to a high desire to share and sacrifice for the organization. On the other hand, high organizational commitment has a negative correlation with the rate of absenteeism and turnover [5], and the degree of slackness in work. [6] [7] The focus of this article is the concept of organizational commitment and leader strategy in building organizational commitment.

\section{ORGANIZATIONAL COMMITMENT AND DIMENSION}

In business dictionary, organizational commitment is defined as "strength of the feeling of responsibility that an employee has towards the mission of the organization". [8] It means that organizational commitment is individual behavior, which is shown by strength of the feeling of responsibility that an employee has towards the vision, mission, goal, and target of organization in future.

Organizational commitment has several dimensions. Meyer \& Allen defined the first dimension (affective commitment) as "positive feelings of identification with, attachment to and involvement in the work organization", and they defined the second dimension (continuance commitment) as "the extent which employees feel committed to their organization by virtue of the costs that they feel are associated with leaving". [9] Added the third dimension (normative commitment). After further research, Allen \& Meyer explains that normative commitment as "the employee's feelings of obligation to remain with the organization". Obligation refers 
to individual responsibility to the continuity of the organization. [10]

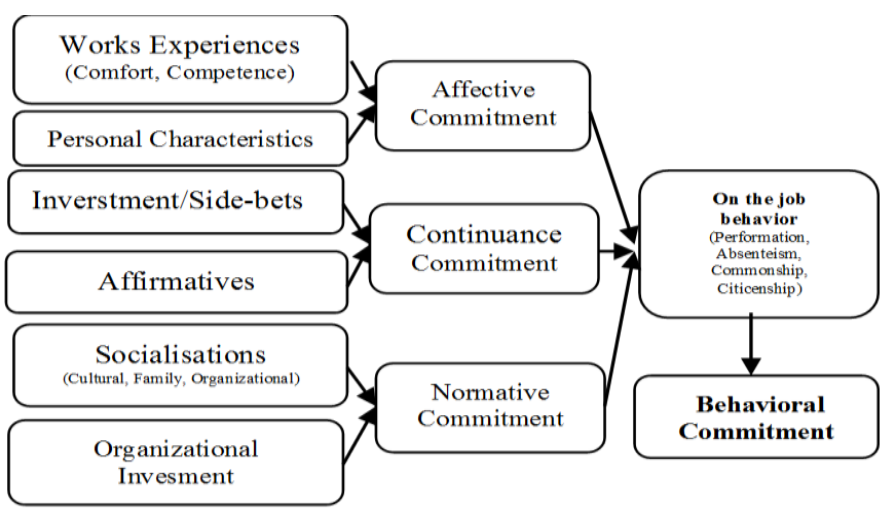

Figure 1. A Three-Component Model of Organizational Commitment

The concept of organizational commitment is described as a three-dimensional concept or model. Meyer \& Allen indicate that the three-dimentional model is to conceptualize organizational commitment. These dimensions are described as the different ways to develop organizational commitment and implicate an employees' behavior in organization as social system. It is shown in Figure 1. Based on Figure 1, three dimensions of commitment has a relation with on-the-job behavior. These are performance, abserteesm, and citizenship. Output from on-the-job behavior is behavioral commitment of employess in organizations.

Meyer \& Allen continue an organizational commitment research. [11] The results are shown in Figure 2.

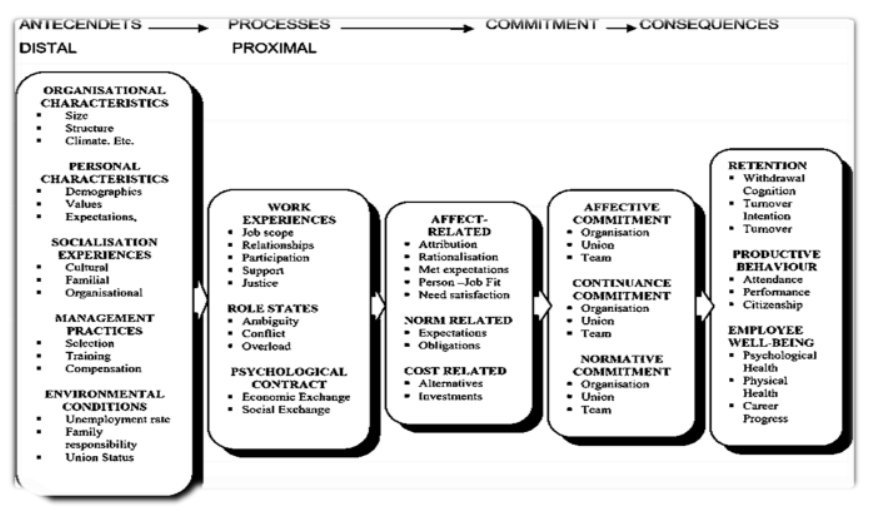

\section{Figure 2. Organizational Commitment Model}

Figure 2 indicates that organizational commitment model has several components. These components are antecendent distal, processes proximal, commitment itself, and consequences of commitment. The affective, continuing, and normative commitment have consequences such as retention (withdrawal cognition, turnover intention, and turnover), productive behavior (attendance, performance, and citizenship), and employees' well-beings (psychological health, physical health, and career progress). All consequences of commitment shoud be managed by the leader in all activities in organization.

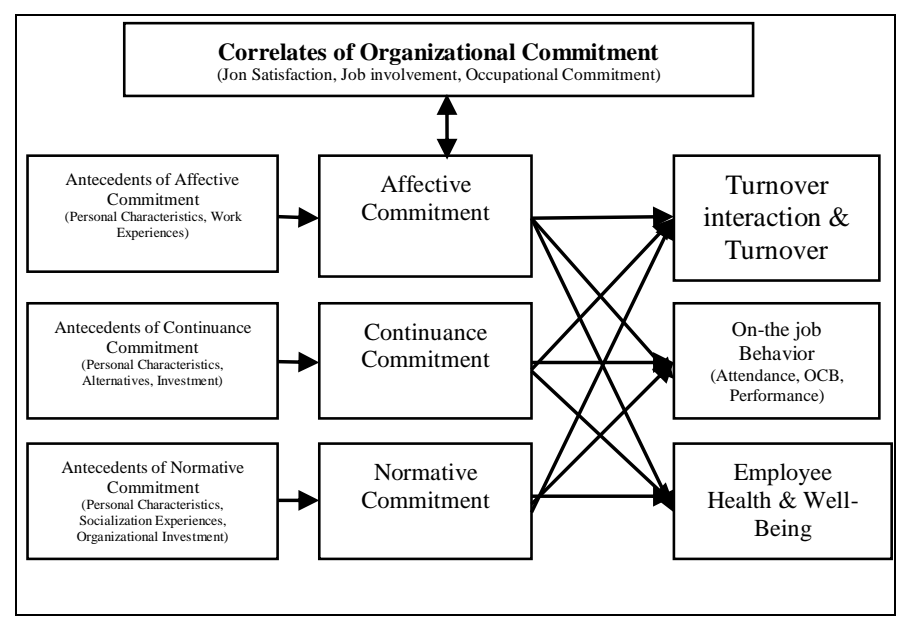

Figure 3. Three-Component Model of Organizational Commitment

Meyer et al have done a research to find the correlation between organizational commitment (three-component model of organizational commitment) and commitment consequences (individual behavior). The results indicate that affective commitment has positive correlation with on-the-job behavior (attendance, performance, and organizational citizenship behavior) and employees' health and well-beings; however, it also has negative correlation with turnover intention and turnover. The continuance commitment has negatif correlation with turnover intention and intention and has netral correlation with on the job behavior, and also employees' health and wellbeings. The last result indicates that normative commitment has negative correlation with turnover intention and turnover and has positif correlation with on the job behavior, employees' health and well beings. Shortly, organizational commitment has significant correlation with commitment consequences in all employees in organization, and this is one of important variables to achieve organizational goal in long term.

\section{LEADER'S STRATEGY IN BUILDING ORGANIZATIONAL COMMITMENT}

iStockphoto explains that "organizational commitment is a spontaneous process, which develops through the orientation of individuals to the organization". Based on the statement, it has a process or strategy to build organizational commitment. In this case, leader's strategy in building members organizational commitment consists of stages and levels [12].

Based on O'Reilly in Unisa, the leader can build organizational commitment through compliance, identification and internalization stages. Compliance or agreement as the first stage focuses around the employee accepting the influence of others mainly to benefit from them. In reality, 
they are theremuneration or promotion form in organizations. This stage is relevant with the continuance commitment dimension. The employees are the ready in organization. The second stage is identification. It occurs when employees accept the influence from others to maintain a satisfactory part of organization. This stage is based on the normative dimension. The last stage is internalization. Thisoccurs when the employee finds the values in organization and based on the affective dimension.

Reichers in Unisa makes different levels of organizational commitment which are related with to building individual's organizational commitment. Figure 4 illustrates the levels of commitment when it increases and when it decreases. Employee's level of commitment may move on from a low level to a higher level of commitment (increasing level commitment or moving on from a higher level commitment to a lower of commitment)

An Increasing Level of Commitment A Decreasing Level of Commitment

\begin{tabular}{|c|}
\hline $\begin{array}{c}\text { Higher level of } \\
\text { organizational } \\
\text { commitment }\end{array}$ \\
\hline
\end{tabular}

\begin{tabular}{|c|}
\hline $\begin{array}{c}\text { Moderate level of } \\
\text { organizational } \\
\text { commitment }\end{array}$ \\
\hline
\end{tabular}

Lower level of
organizational
commitment

Figure 4. Levels of Organizational Commitment Development (Reichers in Unisa)

Below is the effects of organizational commitment described by Lowman. [13] He identified the organizational commitment characteristics as the effects of organizational commitment. This characteristics consist of over-commitment and under-commitment formulated by Lowman and is shown in Table 1.

\begin{tabular}{|c|c|}
\hline Under-Commitment & Over- Commitment \\
\hline $\begin{array}{l}\text { 1. Fear of success. } \\
\text { 2. Fear of failure. } \\
\text { 3. Chronic and persistent } \\
\text { procrastination. } \\
\text { 4. Negative cultural, familiar } \\
\text { personality factors. } \\
\text { 5. Chronic and persistent } \\
\text { underachievement. }\end{array}$ & $\begin{array}{l}\text { 1. Overly loyal employees. } \\
\text { 2. Job and occupational burnout. } \\
\text { 3. Obsessive-compulsive patterns } \\
\text { at work. } \\
\text { 4. Neurotic compulsion to } \\
\text { succeed. } \\
\text { 5. Extreme high level of energy. }\end{array}$ \\
\hline
\end{tabular}

Based on Table 1, it is indicated that characteristics of under-commitment are fear of success, fear of failure, chronic and persistent procrastination, negative cultural, familiar personality factors, chronic and persistent underachievement. If there is any condition that an employee acts that way, the leader should put an effort that the conditions become condusive to pursuit organizational goal. The leader can give something like motivation, discipline, coordination, and communication to the employees. The characteristics of over-commitment are overly loyal employees, job and occupational burnout, obsessivecompulsive patterns at work, neurotic compulsion to succeed, and extreme high level of energy. If there is such an overcommited employee, the leader should put an effort that the conditions become condusive to pursuit organizational goal as well. Finally, the leader's successful strategy in building organizational commitment can be indicated when employes are in optimal condition zone for optimal organizational commitment.

The leader should build organizational commitment of employees by giving motivation, habituation of discipline, cross-functional coordination, employees' involvement in all activities, and multiple ways of communication intensively for his or her organization.The success of the leader's strategy in building organizational commitment is determined by the ability of the leader in understanding the characteristics of subordinates, the situation and the existing environmental conditions

\section{CONCLUSION}

Organizational commitment is individual's behavior which is shown by strength of the feeling of responsibility that an employee hastowards vision, mission, goal, and target of organization in the future. Organizational commitment has three dimensions (affective, continuance, normative commitment). The successful strategy's leader in building organizational commitment can be indicated when employes are in optimal condition zone for optimal organizational commitment. The leader can use his or her strategy to build organizational commitment by giving motivation, habituation of discipline, cross-functional coordination, and employees' involvement in all activities, and multiple ways of intensive communication in organization. The leader should build organizational commitment of theemployees by giving motivation, habituation of discipline, cross-functional coordination, employees' involvement in all activities, and multiple ways of communication intensively and continually for his or her organization.

\section{REFERENCES}

[1] Gandem, I.B. 1999. Penerapan Sistem Jaminan Mutu ISO-9001 di Perum Jasa Tirta. Makalah Seminar dan Lokakarya "Implementasi Konsep TQM untuk Memaksimalkan Daya Saing Organisasi pada Era Globalisasi dan Perdagangan Bebas". Tanggal 8-10 Pebruari 1999. Malang: Universitas Brawijaya.

[2] Buchanan, B. 1974. Building organizational commitment: The socialization of managers in work organizations.Administrative Science Quarterly, 19, 533-546.

[3] Perry \& Rainey .1998. Public-private distintion in organization theory: A Critique and research strategy. The Academy of Management Review. 13 (2), 82-201. Agencies. 
[4] Mowday, R. T; Porter, L. W.; Steers, R. M. 1982 . Employeeorganization linkages: The psychology of commitment, absenteeism, and turnover. New York: Academic Press. ISBN 978-0-12-509370-5.

[5] Meyer J. P.; Stanley D. J.; Herscovitch L. \& Topolnytsky, L. 2002. Affective, Continuance and Normative Commitment to the Organization: A Meta-analysis of Antecedents, Correlates, and Consequences", Journal of Vocational Behavior, Vol. 61, pp. 20-52

[6] Unisa. 2016. Organizational Commitment. (Online). Retrieved from http://uir.unisa.ac.za/ bitstream/handle/10500/1133/04chapter3.pdf. Accesed on March $^{9} 2016$.

[7] Angle, H.L., \& Perry, J.L. 1981. An empirical assessment of organizational commitment and organizational effectiveness.Administrative Science Quarterly, 27, 1-14.

[8] Businessdictionary. 2016. Organizational commitment. (Online). Retrieved

from http://www.businessdictionary.com/definition/organizationalcommitment.html.). Accesed on March16 2016.

[9] Allen, N.J., \& Meyer, J.P.1990. The measurement and antecedents of affective, continuance, and normative commitment to organization.Journal of Occupational Psychology, 63, 1-18.

[10] Meyer, J. P. \& Allen, N. J. 1991 . A three-component conceptualization of organiza-tional commitment. Human Resource Management Review 1: 61. doi:10.1016/1053-4822(91)90011-Z.

[11] Meyer, J.P. \& Allen, N.J. 1997. Commitment in the workplace: Theory, research, and application. Thousand Oaks. CA:Sage.

[12] iStockphoto. 2016. The Three Component Model Of Commitment Improving Commitment And Engagement. (Online). Retrieved from https://www.mindtools.com/ pages/article/three-component-modelcommit-ment.htm. Accesed on March ${ }^{3} 2016$.

[13] Lowman, R.L. 1993. The Inter-Domain Model of Carrer Assesment and Counseling. (Online). Retrieved from http://onlinelibrary. wiley. com/doi/10.1002/j.1556-6676.1993.tb02240.x/ abstract\#publicationhistory. Accesed on October ${ }^{3} 2016$. 